\title{
The Present Tense Usage in Speaking Skill: An Analysis of Students' Short Speech Texts
}

\author{
Hafni Hafsah \\ AMIK Tri Dharma, Pekanbaru, Indonesia \\ hafniedu@gmail.com
}

\begin{abstract}
Received : 2020-10-26
Revised : 2020-11-28

Accepted : 2020-11-30
\end{abstract}

ARTICLE HISTORY

\section{KEYWORDS}

\section{Error analysis}

Simple Present Tense

Speaking

Speech Texts

\begin{abstract}
The result of this paper is based on the data taken from Triskanedi (2007). The study result showed that $80 \%$ of students made mistakes in the use of simple present tense, which was the highest compared to the other two tenses, namely simple past and simple future tense. Due to these interesting findings, the writer intended to carry out further analysis by using the data of the research to find out the kinds of errors produced by the students focusing on simple present tense usage in the short speech texts. The analysis of the data uses a specific type of errors, i.e., omission, addition, missed formation and missed ordering/improper ordering in accordance to taxonomy strategy. The result shows the percentage of the omission of 'be and s/es' is $41.08 \%$. While the addition of 'be and s/es' is $6,21 \%$, and missed formation is $51,94 \%$, and improper ordering is only $0,77 \%$. The omission and addition seem related to the use of 'be' before an adjective or nominal sentence and's' in subject-verb agreement. In addition, the study also found few other errors in using of article 'the', verb inflexion 'ed', and of auxiliary in small numbers. These seems contributed to the students' errors production despite the fact that simple present tense considered as the easiest one to formulate compared to others, another thing that needs to underlie from this study is the understanding of English grammar seems necessary to avoid the same errors in the future.
\end{abstract}

\section{Introduction}

English is essential for everyone in the era of globalization and internationally used as a communication tool. In Indonesia, it is one of the subjects learnt by students at school for several years before entering university. The English language comprises four skills; they are speaking, writing, listening and reading. None of these skills is considered better than the others when it comes to language proficiency and polite usage (Harianja, et al., 2020).

All of them are very important and interrelated. It provides rules in term of grammar as one of an important issue to study. Grammatical competence helps the speaker to use and understand English language structures accurately and immediately, which facilitates their fluency. It was also stated that accuracy is the fluency basis and fluency is an improvement of one's linguistic competence (Abbaspour, 2016) and also the grammatical categories of words and meanings (Nisa, B., 2020)

Subsequently, as English program students, it is required, willy-nilly, to comprehend and master English language skills, which in this case is focusing on speaking. Therefore, the writer intended to find out more in-depth of students' comprehension in speaking through their short speech texts.
Speaking can be defined as the action of conveying information or expressing one's thoughts and feelings in spoken language. Quirk (1987) as quoted by Jhon Triskanedi that speaking expresses thoughts aloud using voice. Speaking is used as a means of communication between two persons or more to convey the purpose of messages through sound. Speaking is a productive skill aside from writing in the English language ever since we use it to produce a message in speech, and it is also known as an active skill. When someone speaks normally, it requires correct grammar and structure in order to be clearly and easily understood by others.

Though some people may think that it does not matter how many errors or mistakes ones make when they speak so long as people understand the messages conveyed, which by this means given that a message seems more important than the structure itself.

The occurrence of this thought might be triggered by ones' capability to speak naturally when they were little without paying attention to the grammar in their native language where an interlocutor still can understand the message. Consequently, people still can speak their language. However, for the students, especially English program students, to meet the requirement of grammatically and structurally correct, they need to find out the errors made while they speak. It is, therefore, necessary to learn about grammar 
component which one of it is tenses, where they are the basic components of speaking.

This paper only focuses on simple present tense errors by making further analysis on students' short speech texts in speaking transcripted in the previous research which was written by Jhon Triskanedi (2007) entitled 'A Study on the Tenses Mistakes by the Third Year Students of English Study Program of Faculty of Teacher Training and Education of University of Riau'. The result of the study showed that $80 \%$ of students made mistakes in the use of simple present tense, which is the highest compared to other two tenses, namely simple past tense and simple future tense.

Brewton et al. (1962:263) quoted by M. Arif Muhsin (2016) stated that the present tense expresses an action or a state of being in the present. The simple present tense is one of the main tenses and the first tense to introduce to students when they start to get engaged with the English language. So, by this judgment, students should not produce a lot of errors, especially for English students program. Rina Listia and Emma Rosana F. (2020) wrote an article entitled, EFL Learners' Problems in Using Tenses: An Insight for Grammar Teaching examined the students' perception on the level of difficulty in learning L2 English tenses on Likert scale 1-5. The result showed that the most straightforward tenses to remember the formula chosen by the university students were and present continuous tense. Further, she mentioned that the students' perception of how the tenses used in the context, still simple present and present continuous tense were the easiest ones compared to others.

Shahin Vaezi and Mehrasa Alizadeh. (2011) wrote an article entitled, How learners cope with English tenses: Evidence from think aloud-protocols stated that correct use of the tense-aspect system of an L2 is a problematic area for most learners especially in a spontaneous oral production They may have a good knowledge base of the L2 temporal system but may find it difficult to implement their declarative knowledge when it comes to practice. That is what makes this area open to research. The researchers also concluded after studied 26 participants of university students that learners with lower language abilities have attended to tense more than aspect while completing the task. Among learners with higher knowledge of English, aspect, as well as tense, was paid attention to.

Furthermore, this research is also aimed at finding out kinds of errors made by the students by using short speech texts in speaking which were delivered and transcribed in the study. It also describes the number and percentage of error in each kind as well as the frequency of occurrence.

While learning language, particularly tenses in English, mistakes and errors can occur during the process of practising. Brown (1980:163) says that a mistake refers to a performance error that is either a random guess or a slip in that is a failure to utilize an available system correctly.

While error Brown (1980:165) refers to a noticeable deviation from the adult grammar of a native speaker, which reflects the inter-language communications of the learners. Usually, learners do not recognize the error due to the gap of language knowledge and unable to correct it. Herawati $\mathrm{Br}$. Bukit and Dila Fitria. (2018) concluded that the students were still lack of knowledge of present tense dramatically, which showed by the errors-occurrence frequency by $50 \%$, which was higher compared to past tense and future tense. And omission was also the highest number which was written in an article entitled An Error Analysis in Tenses Usage by The Students of Management Informatics at Intistut Deli Kesehatan Deli Husada, Deli Tua.

In fact, there are two sources of errors; they are interlingual errors and intralingual errors. Richard (1990) mentioned that interlingual errors are errors caused by the interference of the learner's mother tongue. As an example 'I go to market, I alone do the work', so there is an interference of language pattern of Bahasa Indonesia, and it's different from the use of the English language. While intralingual error as Richard (1990) states that intralingual interference refers to items produced by the learner, which reflect not the structure of mother tongue, but generalization based on partial exposure of the target language, for instance: 'She likes to draw many buildings.' In this sentence, the word 'like' should use $-\mathrm{s}$ at the end of it since pronoun 'she' is the third singular person of subject pronoun.

The other one is buildings is a plural countable noun which grammatically fits with quantifier 'many' not much. Maryana Pandawa (2015) wrote a thesis entitled, An Error Analysis of Speaking Present Tense on English Conversation Program of PRO2 Radio Bandar Lampung, and he concluded that the announcers still committed all the four error types of surface strategy taxonomy. It means that although the announcers had used English in daily activities, they still had a problem with English grammar. In other words, students' seems frequently; they still made many errors in terms of English grammar in pronouns (Syahdan, S., \& Putri, E. U., 2020).

For English program students, to be perfect in English is necessary or excellent. However, in the process of learning, an error can occur a lot of time, and it is unavoidable but still can be minimized. Broughton (1980:139) says that the learners must make errors as an unavoidable and necessary part of the learning process. To do so, this paper analyzes the errors by using error analyzes on which produced from short speech texts in students speaking. In order to analyze the errors, the writer uses a surface structure, which is part of the taxonomy.

The classification of grammatical errors based on surface strategy taxonomy can be classified into (1) 
omission, (2) additions, (3) misinformation, (4) misordering (Dulay, et al., 1982:150).

\section{Method}

This paper is based on the previous research result written by Jhon Triskanedi showed that $80 \%$ of students made mistakes in their short speech texts in speaking, and other tenses like past tense and future tense were only $6.7 \%$ each. The texts use mainly; it is how the large occurrence of mistakes of the tense. However, it is significant to make further analysis of the errors made on the tense in order to provide deeper comprehension on the English language, which in this case is speaking skill.

There are 30 third-year students of English Study Program as a sample for the research, which means there are 30 short speech texts produced in speaking. The list of the text topics that provided as the main instrument of the research are:

a) The Riau province's Major Election 2006

b) The School operational fund

c) The civil servant test

d) The effect of the camera built up the cellular phone for students

e) The campaign against drugs

f) The reinforcement of the traffic regulations in Pekanbaru

g) The regulation for pornography and porn action.

This research applies qualitative research that emphasizes the significance of it. In order to analyze the errors made by the students, the writer uses some steps as mentioned by Theo Van Els, et al., in an article written by Maryana Pandawa (2015), as below:

1) Collecting the data from recording the students' short speech.

2) Transcribing the recording into written or text form.

3) Identifying the errors. The errors are specified by underlining and assigning numerical codes, eg. 1 for misformation, 2 for addition errors, 3 for misformation errors, and 4 for misordering errors.

4) Classifying the errors to find out their frequencies. The errors classified on the surface strategy taxonomy, into categories of omission, addition, misformation, and missed ordering.

5) Calculating the percentage of errors using the following formula:

\section{Total errors in each category $\quad \times 100$ Total errors in four categories (Nation, 1981:58)}

The first and the second steps have already completed in the previous research, which are collecting the data from recording the students' short speech and transcribing the recording into written or text form. The texts were rated by three raters whose professions were lecturers with unquestionable capability on the analytical process. They showed the findings were the same in error percentage, which was $80 \%$.

\section{Result and Discussion}

The result of the data analysis is based on the student's short speech texts used in speaking. The type of errors can be explained as follows;

\subsection{Identifying the errors made by the students.}

The errors are specified by underlining and assigning numerical codes, e.g. 1 for omission errors, 2 for addition errors, 3 for missed formation errors, and 4 for improper ordering errors. Soetikno (1996:181) suggests how the learners may omit necessary items or add unnecessary ones and may misfire an item or miss order them. It is how the surface structure altered as explained below;

a. The error of omission is the absence of an item that must appear in a well-formed utterance. Although any morpheme or word in a sentence is a potential candidate for the omission, some types of morphemes are omitted more than others.

b. The error of addition presences in a specific item must not appear in a well-formed utterance.

c. Missed formation. The wrong form of morpheme or structure, while in omission errors the items are not supplied at all, in missed formation errors the learners supplied something, but it is incorrect.

d. Improper ordering is incorrect placement of a morpheme or group morphemes in an utterance.

Based on table 1, the dominant error is missed formation, which is 67 (sixty-seven) errors, and the lowest one is improper ordering which is only 1 error. At the second place is the error of omission, and the third one is the error of addition lies in the third place with 8 (eight) errors.

Table 1. Type of Errors in Simple Present Tense

\begin{tabular}{ccc}
\hline No & Kinds of Errors & $\begin{array}{c}\text { Number of } \\
\text { Error }\end{array}$ \\
\hline 1 & Error of omission & 53 \\
\hline 2 & Error of Addition & 8 \\
\hline 3 & Missed formation & 67 \\
\hline 4 & Improper Ordering & 1 \\
\hline
\end{tabular}

\subsection{Classifying the errors}

They were classified based on the surface strategy taxonomy, divided into categories of omission, 
addition, missed formation, and missed ordering/improper ordering. Based on the analysis, the result shows as follows;

\section{A. Omission}

After making an analysis on the data, there are 53 (fifty-three) errors in omissions found, namely;

a. omission of-s/es

In this category of omission, it was (forty-six) of errors, for example:

identified 46

- because people or teenager don't

- just because anybody use it

- It is no payment for who.... whoever pass the test or not

- Technology has become our close friend that always work together

The correct sentences should be;

- because people or teenagers don't

- just because anybody uses $i t$

- $\underline{\text { There }}$ is no payment for who.......whoever passes the test or not

- Technology has become our close friend that always works together

b. Omission of - be

There are 6 (six) errors of omission of be, they are:

- this the beginning of problem

- there must no discrimination

- because the size, very the small size

- we proud of our country

The correct sentences should be:

- this $\underline{\text { is }}$ the beginning of the problem

- there must be no discrimination

- because the size is very small

- we are proud of our country

\section{B. Errors of Addition}

Errors of addition are characterized by the presence of one or more items that must appear in well-formed sentences.

\section{a. Addition of -s/es}

- Parents who gives this facility to their

- Children and also student uses hand pone

- People who disagree with this rules says that

The correct sentences should be:

- Parents who give this facility to their

- Children and students also use hand phone

- People who disagree with these rules say that

\section{b. Addition of-be}

For instance;

- It is not necessary to be explained

- This is become the mighty case

- So they are forget to study

- Sometimes they are lie that they need

The correct sentences should be:

- It is not necessary to explain

- This becomes the mighty case

- So they forget to study

- Sometimes they lie that they need

\section{Missed Formation}

Error in Missed formation is the biggest numbers found in the students' short speech texts.

- The civil servant entrance is done one time a year

- There are many profession that is included

- $\quad$ It is no payment for who.... whoever pass the test or not

- They can transfer or send the pictures to the friend to the phone

- $\quad$ So they are forget to study, to library

- There is so much film that relate to pornography

- This regulation should be made or arranged of local government

- $\quad$ am not agree because

The correct sentences should be:

- The civil servant entrance is done once in a year or one time in a year

- There are many professions that are included

- $\quad$ There is no payment for who. whoever passes the test or not

- They can transfer or send the pictures to their friends' phone

- $\quad$ So they forget to study, to go to library

- There are so many films that relate to pornography

- This regulation should be made or arranged by local government

- $\quad$ I do not agree because

\section{Improper Ordering}

It is characterized by the incorrect placement of a morpheme or sequence. For example:

- And also it can the students can copy the book something sacred that poses by other

The correct sentence should be:

- $\quad$ And also the students can copy the book which is something sacred that posed by others 
Based on the error type, the percentage of errors as showed on table 2. The highest percentage showed by error of formation which is $51.93 \%$.

Table 2. Percentage of each types of error

\begin{tabular}{lll}
\hline Types of Error & Total Error & $\begin{array}{l}\text { Percentage of } \\
\text { Error }\end{array}$ \\
\hline Error of omission & 53 & 41.09 \\
\hline Error of Addition & 8 & 6.20 \\
\hline Missed formation & 67 & 51.93 \\
\hline Improper Ordering & 1 & 0.78 \\
\hline Total of error & 129 & $100 \%$ \\
\hline
\end{tabular}

The number of the errors of each type are also clearly drawn on Graph 1.

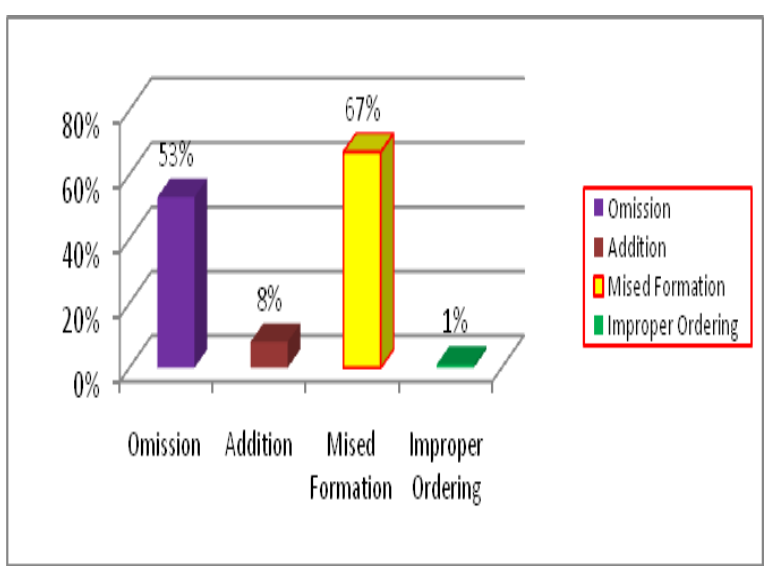

Graph 1. Number of each Error

While on table 3, it describes the frequency of occurrence of each error. The highest one is the error in missed formation which is $51,94 \%$, followed by the error of omission $41.08 \%$, and error of addition, the last on is improper ordering.

Table 3. Frequency of occurrence of each error type

\begin{tabular}{lcccc}
\hline $\begin{array}{l}\text { Types } \\
\text { Error }\end{array}$ & of & $\begin{array}{c}\text { Number } \\
\text { of Error }\end{array}$ & $\begin{array}{c}\text { Percentag } \\
\text { e of errors }\end{array}$ & $\begin{array}{c}\text { Total } \\
\text { Error }\end{array}$ \\
\cline { 2 - 4 } & s/es & 47 & $36,43 \%$ & \\
\cline { 2 - 4 } Omission & $\mathrm{Be}$ & 6 & $4,65 \%$ & $41,08 \%$ \\
\hline \multirow{2}{*}{ Addition } & $\mathrm{s} / \mathrm{es}$ & 3 & $2,33 \%$ & \multirow{2}{*}{$6,21 \%$} \\
\cline { 2 - 4 } & $\mathrm{Be}$ & 5 & $3,88 \%$ & \\
\hline $\begin{array}{l}\text { Missed } \\
\text { formation }\end{array}$ & 67 & $51,94 \%$ & $51,94 \%$ \\
\hline $\begin{array}{l}\text { Improper } \\
\text { Ordering }\end{array}$ & 1 & $0,77 \%$ & $0,77 \%$ \\
\hline $\begin{array}{l}\text { Total of } \\
\text { error }\end{array}$ & $100 \%$ & & & \\
\hline
\end{tabular}

Based on the findings mentioned above on table 1 , the dominant error lies on the missed formation which is 67 (sixty-seven) errors and the lowest one is improper ordering which is only 1 (one) error. This situation means that the students found it hard to form good sentence structure with the right-words arrangement but seemed to have better understanding of making proper placement of words in sentences. While the second is an error of omission, which the students failed to add -'s/es or -be' in order to complete the verb or nominal sentences in simple present tense form. The error of addition lies in the third place with 8 errors where the students failed to omit 's/es' or 'be' in the sentences, which they have to understand the correct use of both in nominal and adjective-related sentences. While table 2 shows the percentage of each type of error which is gained from the data on table 1 by using a calculation.

Based on the frequency of occurrence of each error type, the highest error is missed formation which is $51.94 \%$, while improper ordering by $0.77 \%$ which hardly occur or only once, which can be seen on the sentence stated in errors classification on point D. In general, the kinds of the error made by the students is in word forms such as noun and adverb, quantifier, improper 'be ' use in a subject- verb agreement, the omission of article 'the and a', preposition and to infinitive, which all of these issues would make a contribution to the well-formed sentence structure.

As an addition to the findings, the writer also found a few other errors in using the article 'the', verb inflection'-ed', and auxiliary.

\section{Conclusion}

The highest error in missed formation explains that the students of the third year of the English Program still find it challenging to fit the words into a sentence by using the correct structure. Students also failed to add the use of 's/es' in sentences which existed in quite large numbers. Though some research papers stated that simple present tense is easier to understand compared to other tenses, somehow, the errors are still taken place. Hence, it is necessary for everyone who studies tenses, precisely simple present tense, to practice more to construct correct sentences structurally and grammatically.

\section{References}

Bukit, B.H (2018). An Error Analysis in Tenses Usage by The Students of Management Informatics at Institute of Deli Kesehatan Deli Husada Deli Tua. [Unpublished Thesis. Amik Tridarma].

Brown, H. D, 1980. Principles of Language and Teaching. Prentice Hall, Inc. New Jersey. 
Dulay, H., Marina, B., \& Krashen, S. (1982). Language Two. New York Oxford University Press.

Harianja, R., Yudar, R. S., Deliani, S., Nursafira, M. S., \& Hamuddin, B. (2020). An Analysis of Pronouns Used in Selected International Journal Articles: Exploring Authors' Flexibility and Consistency. REiLA : Journal of Research and Innovation in Language, 1(3), 83-88. https://doi.org/10.31849/reila.v1i3.3839

Herring, P. (2016). The Farlex Grammar Book. Complete English Grammar Rules. Farlex International

James, C. (1998). Error in Language Learning and Use: Exploring Error Analysis. Longman Group Ltd. London.

Listia R. and Febriyanti E. (2020) "EFL Learners' Problems in Using Tenses: An Insight for Grammar Teaching", IJET (Indonesian Journal of English Teaching), 9(1), 86-95. https://doi.org/10.15642/ijet2.2020.9.1.86-95.

Muhsin, M. A. (2016). Analyzing the students' errors in using simple present (A case study at Junior High School in Makassar). Pacific Science Review B: Humanities and Social Sciences, 2(3), 81-87.

Nisa, B. (2020). A Morphological Process of Derivational Affixes in Popular LINE Webtoon: The Annarasumanara. REiLA : Journal of Research and Innovation in Language, 2(2), 8592. https://doi.org/10.31849/reila.v2i2.4656

Pandawa, M. (2015, July). An Error Analysis of Speaking Present Tense on English Conversation Program of PRO 2 Radio Bandar Lampung. In Proceeding International Multidisciplinary Conference on Social Sciences (IMCoSS) (Vol. 1, p. 5).

Richards, J.C. (1990). Error Analysis. Perspectives on Second Language Acquisition. Routledge.

Setiyadi, B. 2006. Metode Penelitian untuk Pengajaran Bahasa Asing Pendekatan Kualitatif dan Kuantitatif. Yogyakarta: Penerbit Graha Ilmu.

Soetikno, L. (1996). Analysis Wacana. Grameda Pustaka Utama. Jakarta.

Tarigan, H.G., \& Tarigan, D. (1990). Pelajaran Analissi Kesalahan Berbahasa. Bandung: Tarsito.

Triskanedi. Jhon. (2007). A study on the Tenses Mistakes By The Third Year Students of English Study Program of FKIP UNRI in Speaking. [Unpublished Thesis. Universitas Riau].
Vaezi, S., \& Alizadeh, M. (2011). How learners cope with English tenses: Evidence from think-aloud protocols. Procedia-Social and Behavioral Sciences, 29, 986-993.

Quirk, R, (1987). Longman Dictionary of Contemporary English-New Edition. London. Longman INC. 